\title{
GLAZBENI ŽIVOT DUBROVNIKA U 15. I 16. STOLJEĆU
}

\author{
Marina Mrđen \\ Filozofski fakultet u Splitu \\ Odsjek za povijest \\ marina.mrden@gmail.com \\ Stručni rad \\ Primljeno: 5. 2. 2019. \\ Prihvaćeno: 14. 10. 2019.
}

\begin{abstract}
Glazba je oduvijek bila važan dio čovjekova života. Ona je nudila ljudima svojevrstan odmak od stvarnosti odvodeći ih u svijet slobode, nesputanosti mašte. Upravo ta povezanost s ljudskom svakodnevicom uvjetovala je razvoj glazbe koji se specifično odrazio na određenim prostorima u različitim razdobljima. U ovom radu bavit ćemo se razvojem i ostvarenjima renesansne glazbe u Dubrovniku. Dubrovačka Republika je, osobito početkom 15. stoljeća, bila pod velikim utjecajem talijanskih razmišljanja i nazora. Taj se utjecaj odrazio i na glazbenu umjetnost. Naime, mnogi dubrovački glazbenici primili su svoje formalno glazbeno obrazovanje u nekom od većih talijanskih gradova koji su bili središnje točke europske renesanse. Ondje su također svjedočili izvedbama velikih glazbenih djela nastalih iz pera talijanskih skladatelja te su ih, neposredno nakon premijera, izvodili u Gradu. Osim talijanskih glazbenika, u Dubrovniku je djelovao i znatan broj drugih glazbenika stranoga podrijetla koji su također ostavili svoj trag na dubrovačku glazbu. Glazba ovoga vremena razvija se u dva različita pravca slijedeći srednjovjekovnu glazbenu tradiciju. S jedne strane možemo pratiti razvoj crkvene glazbe koja se temeljila pretežito na vokalnoj tradiciji uz postepeno obogaćivanje instrumentalnom pratnjom, dok s druge strane uočavamo pojavu profesionalnih svirača svjetovne glazbe unutar glazbenoga tijela Kneževe kapele. Osim crkvenih i svjetovnih institucija u kojima se njegovala profesionalna glazba, na dubrovačku glazbu također je značajno utjecalo i narodno glazbeno stvaralaštvo u kojem su se na specifičan način preplitali elementi vokalne i instrumentalne glazbe s plesom. U renesansnom se Dubrovniku veoma rado muziciralo u okviru raznih službenih i neslužbenih događaja. U službenim prilikama, poput proslava velikih kršćanskih blagdana, poklada i sl., glazbenici Kneževe kapele izvodili su reprezentativnu glazbu u čast Republici. Glazba se ipak češće izvodila u neformalnom okruženju. Tako se na raznim događajima, počevši od krštenja, svadbi, pogreba itd. mogla čuti svirka glazbenika Kneževe kapele te glazbenika amatera. Dubrovački glazbenici također su često imali gostovanja na dvorovima vladara susjednih država. Nažalost, o glazbenom svijetu Dubrovnika 15. i 16. stoljeća do danas svjedoče samo malobrojni sačuvani notni ostaci pojedinih skladbi te određena arhivska vrela koja nam mogu poslužiti za vrednovanje dubrovačkih glazbenih ostvaraja toga vremena te bolje razumijevanje uloge glazbe $i$ njezine povezanosti sa svakodnevnim životom.
\end{abstract}

Ključne riječi: Dubrovačka Republika, crkvena i svjetovna glazba, glazbenici, instrumentarij, državni ceremonijal, svakodnevica, 15. i 16. stoljeće 


\section{Renesansna glazba na hrvatskim prostorima}

Razdoblje renesanse u glazbi započinje 1430. te traje sve do 1600. godine. U tom se razdoblju prvi put u povijesti glazbe pojavljuje stilsko jedinstvo na europskoj razini inspirirano antičkim kulturno-umjetničkim tekovinama.

U 14. stoljeću duh humanizma odjeknuo je u glazbenoj umjetnosti pojavom ars nove. ${ }^{1}$ To je također vrijeme u kojem dolazi do afirmacije francuskih zemalja kao značajnih glazbenih središta. U hrvatskim gradovima nailazimo na spomen raznih anonimnih i poznatih glazbenika koji su svirali različite instrumente. Tako se u Dubrovniku spominju svirači puhačkih i žičanih instrumenata, bubnjeva te orgulja uz koje djeluju tzv. pjevači-lakrdijaši te narodni pjevači.

U 15. stoljeću nizozemske zemlje ${ }^{2}$ ostvaruju povoljne uvjete za kulturno-umjetničku djelatnost te se ondje pojavljuje niz nizozemskih polifoničara koji preuzimaju vodstvo u europskoj glazbi tijekom sljedećih dvaju stoljeća. Najveće dostignuće nizozemskih polifoničara bilo je usavršavanje polifonoga sloga ${ }^{3}$ te širenje glazbene pismenosti osnivajući brojne crkvene i dvorske ustanove za školovanje glazbenika. Već krajem 15. stoljeća talijanska se polifonija mediteranskoga temperamenta ${ }^{4}$ pomalo počinje oslobađati od flamanskoga utjecaja što je rezultiralo nastankom madrigala i frottole početkom sljedećega stoljeća. ${ }^{5}$

Šesnaesto stoljeće u Europi obilježeno je djelovanjem triju ideoloških pravaca - mediteranske renesanse, protestantske reformacije i katoličke protureformacije. Ovo je doba u kojem vokalna polifona glazba i višeglasna zborska a cappella glazba doživljavaju svoj vrhunac. Istovremeno dolazi do osamostaljenja i profesionalizacije instrumentalne glazbe; osobito glazbe skladane za lutnju, orgulje i čembalo; te razvoja

1 Josip Andreis, Povijest glazbe I., 171-173.: Ars nova naziv je za glazbeno razdoblje od 1320. do 1380. godine. To je vrijeme kada se, pod utjecajem humanističkih ideja, poseže za svjetovnim glazbenim predlošcima namjesto uobičajenih crkvenih tekstova latinskoga podrijetla. Najčešće su izvođeni polifonski glazbeni oblici tzv. dvostrukoga moteta i višeglasnoga Lieda.

2 Isto, 223-305.: Sjeveroistok Francuske tj. područje Burgundije bilo je prvo središte nizozemske polifonije, a potom se centar premješta u Belgiju i Nizozemsku.

3 Isto: Uvođenjem polifonoga sloga posebno se isticalo značenje samog teksta.

4 Isto: Gradovi Venecija, Rim, Firenza, Ferrara, Mantova i Milano bili su glavna središta razvoja talijanske polifonije.

5 Isto: Frottola nastaje u Italiji, a madrigal kao najznačajnija pojava u europskoj svjetovnoj vokalnoj polifoniji rezultat je suradnje talijanskih i nizozemskih majstora. 
instrumentalne notacije. Najzastupljeniji glazbeni crkveni oblici u renesansi bili su misa kao središnji oblik duhovne glazbe, motet i lauda; dok su se od svjetovnih oblika isticali madrigal, frottola $i$ chanson. Krajem stoljeća u Italiji nastaje prva opera Dafne, autora Jacopa Perija (1561. - 1633.) s kojom je naznačen početak novoga glazbenog razdoblja - baroka.

Dok su se hrvatske zemlje u 16. stoljeću našle u poprilično nepovoljnim društvenim, gospodarskim i kulturnim prilikama, Dubrovačka Republika uživala je razdoblje mira i prosperiteta. Sačuvan je spomen na samo desetak hrvatskih renesansnih glazbenika među kojima se ističu Franciscus Bossinensis (Franjo Bosanac), Andrea Antico da Montona (Andrija Motovunjanin), Andrea Patrizi (Andrija Petrić) i Giulio Schiavetto (Julije Skjavetić) kao autori čiji je skladateljski opus sačuvan do danas. Uz njih se spominju i dubrovački skladatelji: Sekundo Brugnoli, Gavro Temparičić, Benedikt Babić, Marin Držić, Emanuel Zlatarić te Antun Tudorović čija je glazbena ostavština izgubljena. ${ }^{6}$

\section{Crkvena glazba u renesansnom Dubrovniku}

Ostvarenja dubrovačke renesansne crkvene glazbe vjerojatno su dosegla visoku razinu. ${ }^{7}$ Crkvena glazba nastavila se na srednjovjekovnu pjevačku tradiciju ${ }^{8}$ koju su u prvom redu njegovali pripadnici redova franjevaca i dominikanaca. U to vrijeme kanonik cantor organizirao je i vodio crkveno pjevanje u katedralnoj crkvi, dok su pjevačkim zborovima u ostalim crkvama upravljali chori moderatori. Pjevačku službu obavljali su samo muškarci u sastavu muškoga ili mješovitoga muškog zbora. ${ }^{9}$ Glazba se svakodnevno izvodila u katedrali svete Marije te ostalim dubrovačkim crkvama, a bogoslužje je bilo osobito svečano prilikom raznih crkvenih svečanosti te kada je bilo dijelom državnoga ceremonijala. ${ }^{10}$

6 Josip Andreis, Povijest hrvatske glazbe IV., 1974., 42., 171-181., 223-311.; Leksikon Marina Držića. Preuzeto s: http://leksikon.muzej-marindrzic.eu/glazba/ (20. 7. 2017.); Lovro Županović, Stoljeća hrvatske, 1980., 20-21., 56-60.

7 Miho Demović, Glazba i glazbenici u Dubrovačkoj Republici: od početka XI. do polovine XII: stoljeća, 1981, 44.: Katolicizam postaje temeljnim političkim identitetom Republike u vremenu kada se ona nalazi na raskrižju kršćanskoga i muslimanskoga svijeta. Stoga su državne vlasti brinule o reprezentativnosti crkvenih institucija i svečanosti.

8 Isto: Tijekom kasnoga srednjovjekovlja pojavljuje se znatan broj obrazovanih crkvenih pjevača koji su svoje znanje stjecali u okviru petogodišnjih katedralnih škola.

9 Isto: Najviše dionice izvodili su dječaci.

10 Isto, 63.: Tada je na misnom slavlju prisustvovao sam knez kao i predstavnici vlasti. 
O razvijenosti dubrovačke crkvene glazbe svjedoči činjenica da su već u 13. stoljeću u Gradu postojale orgulje te da je djelovao katedralni zbor kanonika. ${ }^{11}$ To nas upućuje i na postojanje kvalificiranih orguljaša i zborovođa koji su, zbog odličnoga poznavanja glazbene teorije, često bili najobrazovaniji glazbenici svoga vremena. ${ }^{12}$ Govoreći o dubrovačkoj crkvenoj instrumentalnoj i vokalnoj glazbi, potrebno je istaknuti i utjecaj flamanskih majstora koji su djelovali u Dubrovniku. ${ }^{13} 0$ bogatstvu renesansne crkvene glazbe ponajviše nam svjedoče glazbeni arhivi dominikanskoga i franjevačkoga ${ }^{14}$ samostana. ${ }^{15}$

\section{Svjetovna glazba u renesansnom Dubrovniku}

Svjetovnu glazbu možemo promatrati s dvaju aspekata. Prva bi sfera svakako bila folklorni izričaj, glazba koja je iskonski nastajala u narodu te se s vremenom mijenjala i prenosila na buduće generacije. S druge strane, imamo pojavu profesionalnih glazbenika, usavršavanja glazbenih instrumenata i umijeća sviranja u smjeru klasične glazbe. S obzirom na to da se klasična glazba razvila iz folklora, možemo je promatrati kao preoblikovan i usavršen oblik narodne glazbe. Dok je folklorna glazba većinom veseloga i plesnoga karaktera, klasična glazba obično je umjerenijega tempa te „ozbiljnijega” karaktera. Također, uočava se i razlika između instrumenata koji se koriste u folklornim i profesionalnim ansamblima.

\section{Folklorna tradicija}

Mnogi folklorni plesovi i popijevke sačuvani do danas u Hrvatskoj, kao i drugdje u svijetu, vuku korijene iz starine. Neki su od njih sigurno potekli iz renesansnoga razdoblja, ali su u vremenu svoga nastanka

11 Demović, Glazba i glazbenici, 63.: U 13. stoljeću pri katedralnom zboru djelovalo je 26 kanonika.

12 Isto: Prvi poznati dubrovački orguljaš bio je Nikola Pavličević. On je obavljao službu orguljaša stolne crkve od 1448. do 1466. godine.

13 Isto: Flamanski glazbenici osobito su zaslužni za uvođenje nove vokalne tehnike te polifonoga načina pjevanja.)

14 Robin Harris, Povijest Dubrovnika, 2006., 221-246.: U dubrovačkom franjevačkom samostanu nalazi se najveća zbirka muzikalija u Dalmaciji.

15 Demović, Glazba i glazbenici u Dubrovačkoj Republici: od početka XI. do polovine XVII. stoljeća, 44., 63.; Harris, Povijest Dubrovnika, 221-246.; Koraljka Kos, „,Muzički instrumenti u srednjovjekovnoj likovnoj umjetnosti Hrvatske”, Rad, (1969), 351/2, Zagreb; 197. 199.; Enio Stipčević „Dominikanci i glazba u Hrvatskoj (16.-20. Stoljeće)”, Preuzeto s: https://hrcak.srce.hr/74297 (13.8.2018). 
to bili umjetnički plesovi i popijevke za koje se onodobno znalo tko ih je izmislio, spjevao ili uglazbio. Izvedba folklorne glazbe iziskivala je i izradu specifičnih tradicionalnih folklornih instrumenata. Dubrovački kraj diči se bogatstvom i velikom raznovrsnošću tih narodnih instrumenata među kojima su se isticali lijerica, mješnica te gusle. Lijerica, glazbalo slično manjoj violini pokretljivih mogućnosti muziciranja, zauzima ipak najznačajnije mjesto u dubrovačkoj folklornoj tradiciji. Osim sviranja žica, glazbu je pratio ritmični zvuk udarca sviračeve noge o pod koji je oživljavao samu svirku.

Folklorna glazba nije se izvodila prema notnom predlošku, već se prenosila s generacije na generaciju uključujući brojne improvizacije. Najbolji glazbenici bili su upravo oni koji su najvještije iskoristili tu slobodu improviziranja stilova na razne poznate plesne i druge napjeve. U razdoblju između 15. i 17. stoljeća improviziranje nazivano „pripijevanje” bilo je veoma uobičajeno. Takav je glazbeni izraz danas nestao na prostoru Dubrovnika, ali je zadržan u Dalmatinskoj zagori te susjednoj Hercegovini. „Pripijevanje” je opisivalo događaje i osobe iz svakidašnjega života, a tekstovi pjesama često su bili podrugljivoga tona. Stoga je često dolazilo do fizičkih obračunavanja i podnošenja tužbi upravo zbog uvredljivih tekstova. Primjerice, zabilježen je spor iz 1462. godine jer je grupa od četrdesetak mladića u dubrovačkoj Širokoj ulici pripijevala ove stihove koji su uvrijedili plemića Klementa Gučetića te ih je on zbog njih tužio sudu:

„O Jelo, vita jelo,

ne hod sama na vodu!

Klimoje je na vodi. / Klimoje sjedi na vodi."16

\section{Ljubavna lirika i klapsko pjevanje}

Umjetnička ljubavna lirika starih dubrovačkih trubadura Šiška Menčetića, Džore Držića i dr., jedan je od značajnijih aspekata narodnoga glazbenog stvaralaštva u Dubrovniku. Ti ljubavni stihovi nastaju pod utjecajem talijanske vokalne lirike, a vjerojatno su ih dubrovački humanisti - trubaduri izvodili kao jednostavne popijevke uz leut. ${ }^{17}$

16 M. Demović, Glazba i glazbenici, 19-22.; Miho Demović, „Glazba u renesansnom Dubrovniku”, Dani Hvarskog kazališta: Građa i rasprave u hrvatskoj književnosti i kazalištu 14/1 (1998), Preuzeto s: https://hrcak.srce.hr/file/152541 (5.7.2017).: Ovi stihovi podrugljivog su karaktera jer upućuju na preljub djevojke koja samostalno odlazi po vodu gdje je čeka drugi muškarac.

17 Andreis, Povijest hrvatske glazbe, IV., 41.: Ljubavna lirika nazivala se i pučko-leutaškom lirikom, iako nije nužno uvijek izvođena uz leut. 
Ljubavna je lirika u Dubrovniku zaživjela u drugoj polovici 15. stoljeća te je doživjela vrhunac 1507. godine kada dubrovački vlastelin Nikša Andretić Ranjina (o. 1494. - nakon 1582.) objavljuje najznačajniji ljubavni kanconijer hrvatske renesansne književnosti.

Donosimo primjer teksta jedne svjetovne lirske ljubavne pjesme koju su „dubrovački vlasteličići” pjevali u svojim uredima krateći vrijeme:

„Sada sam ostavljen

srid morske pučine

valovi moćao bj’en

daž dojde s visine.

Kad dojdoh na kopao,

mnih da sam..."

U Ranjininu zborniku zapisano je osamsto dvadeset ljubavnih pjesama pisanih dvanaesteračkim dvostruko rimovanim distihom ${ }^{18} \mathrm{koje}$ su se u to vrijeme pjevale u Dubrovniku, a većina njih nastaje iz pera Šiška Vlahovića Menčetića i Džore Držića. Njih su naslijedili Marin Držić, Nikola Nalješković i Nikola Dimitrović, druga generacija pjesnika renesansne ljubavne lirike. Pjesme koje su spjevali ovi pjesnici bile su toliko popularne da je u prvoj polovici 16. stoljeća ljubavna lirika postala dominantan književni pravac diljem Jadrana. Ljubavno pjesništvo protkalo se tako u umjetničko i pučko pjesništvo te postalo dijelom duhovne, satiričke i prigodne poezije, epova i poema, proznih i dramskih tekstova. Sredinom 16. stoljeća nastaju slavni kanconijeri Marina Držića i Hanibala Lucića te tada renesansna ljubavna lirika doživljava svoj estetski vrhunac. Tada su ljubavni dvanaesterci postepeno gubili značaju povratkom petrarkističkom idealu i osmeračkom stihu. ${ }^{19}$

Godine 1979. Koraljka Kos donosi hipotezu o izvođenju ljubavne lirike i dvanaesteračkih stihova. Naime, ona smatra da je dio lirske poezije dubrovačkih renesansnih pjesnika bio uglazbljen u obliku popijevki pjevanih uz leut koje su imale simetričnu ritamsko-metričku strukturu. Glazba se u pojedinim kiticama ponavljala dok je lutnja samostalno nastupala u interludijima i u postludijima. Njezinu hipotezu podupire Jakša Primorac ističući teoriju formularnoga pamćenja Alberta Batesa Lorda kojom ističe da je običan puk mogao lako pamtiti dvostruko rimovane dvanaesterce ljubavne lirike te ih prenositi

18 Jakša Primorac, Poj ljuveni: Pučko pjevanje u renesansnoj Dalmaciji, Split, 2013., 22.-26.: Unatoč snažnom Petrarcinu utjecaju, ova je vrsta rime srodna Marulićevoj Juditi.

19 Primorac, Poj ljuveni, 22-26.: Povratak petrarkista pjesmama Dinka Ranjine i Dominika Zlatarića. 
mlađim naraštajima. Dokaz za to pronalazi u trećem izdanju Ranjinina zbornika u kojem prevladavaju anonimni autori koji su slobodno preuzimali najefektnije dvostihe Džore Držića i Šiška Menčetića te ih, s nešto manje pjesničkoga umijeća, uklapali u svoje pjesme. ${ }^{20}$

\section{Kneževa kapela}

Jedan od najznačajnijih nositelja svjetovnoga glazbenog života u Republici bila je Kneževa kapela, glazbeno tijelo pod državnim pokroviteljstvom sastavljeno od svirača raznovrsnih instrumenata. Kneževa je kapela u Dubrovniku ustanovljena, po uzoru na slične kapele koje su postojale na zapadnoeuropskim dvorovima, početkom 14. stoljeća. ${ }^{21} \mathrm{~S}$ obzirom na to da je osnovana s ciljem da se u njoj ogleda sva slava i ugled Dubrovačke Republike, kako unutar njezinih granica, ${ }^{22}$ tako i izvan njih, ${ }^{23}$ predstavnici vlasti brinuli su se za održavanje visoke razine kvalitete izvođenja glazbe te za sam izgled glazbenika. Prvi poznati svirači Kneževe kapele bili su gradski trubači iz redova zdura i teklića, ${ }^{24}$ no nedugo se zatim u arhivskim vrelima spominju i brojni drugi instrumenti koji su bili u njezinu sastavu, poput trombona, raznih manjih puhačkih glazbala, harfi, lutnji, bubnjeva i dr.

Sastav Kneževe kapele mijenjao se iz godine u godinu. Temeljem sačuvane arhivske građe uočavamo da je broj stalno zaposlenih glazbenika bio razmjerno velik te je obuhvaćao glazbenike domaćega i stranoga podrijetla ${ }^{25}$ koje je predvodio najvještiji svirač nazivan maestro di cappella. ${ }^{26}$

20 Andreis, Povijest hrvatske, IV., 41.; Demović, „Glazba u renesansnom.” Preuzeto s: https:// hrcak.srce.hr/file/152541 (5.7.2017); Dragić, Poetika i povijest. Preuzeto s: https:// www.ffst.unist.hr/images/50013808/poetika\%20i\%20povijest.pdf (15.9.2017.); Kos, „Muzički instrumenti,” 238-242.; Milorad, Povijest hrvatske, I., 123.

21 M. Demović, „Glazba u renesansnom“: Djelovanje Kneževe kapele prekinuto je za velikog potresa 1667. godine. Njezin rad nastavljen je djelovanjem Kneževa orkestra u 18. stoljeću, glazbenoga tijela koje je prestaje postojati padom Dubrovačke Republike.

22 Isto: Glazbenici Kneževe kapele uveličavali su svojom svirkom proslave svih značajnijih crkvenih svetkovina, društvena i sl. zbivanja, vojne parade itd.

23 Isto: Prilikom brojnih gostovanja na dvorovima stranih vladara od kojih su najučestalija bila upravo gostovanja na dvorovima bosanskoga kralja i hercegovačkih velikaša.

24 Demović, Glazba i glazbenici, 69.: Gradski glasonoše koji su bili zaduženi za proglašavanje odredbi dubrovačkog kneza. Svoj proglas započinjali su zvukom trube koja je signalizirala narodu da se okupi.

25 Demović, „Glazba u renesansnom”: Među glazbenicima stranoga podrijetla Demović ističe glazbenike iz Albanije, Austrije, Belgije, Bosne, Francuske, Grčke, Italije, Nizozemske, Njemačke, Španjolske i Švicarske.

26 Demović, Glazba i glazbenici, 69.; Demović, „Glazba u renesansnom” 


\section{Službovanje u Kneževoj kapeli}

Stjecanjem glazbenoga obrazovanja i svladavanjem umijeća sviranja glazbenici Kneževe kapele uživali su veliki socijalni ugled te su mogli osigurati sve povoljnosti potrebne za pristojan život. S obzirom na to da su djelovali unutar državnoga tijela, smatrani su ljudima od državnoga povjerenja te su mogli uživati u neposrednim kontaktima sa samim državnim vrhom. Ipak, postojala je znatna razliku između glazbenika koji su bili u stalnoj službi Kneževe kapele te onih koji su bili angažirani samo u određenim prilikama. Glazbenici koji su djelovali u stalnoj službi nazivali su se piffari te su imali stalnu mjesečnu plaću koja je iznosila do 210 dubrovačkih perpera.

S druge strane nalazili su se trubači i bubnjari koji su bili angažirani za obavljanje signalnih funkcija ${ }^{27}$ pri gradskoj straži, na tvrđavama, u brodovima i sl. Unatoč svojoj primarno funkcionalnoj svrsi, također su ponekad nastupali s piffarima u crkvenim svečanostima i u državom ceremonijalu. ${ }^{28}$ Za svoj rad primali su minimalnu plaću koja je iznosila otprilike 20 perpera te se, za razliku od piffara, nisu mogli baviti isključivo glazbenim zvanjem niti se pretjerano posvetiti daljem razvijanju svojih glazbenih sposobnosti.

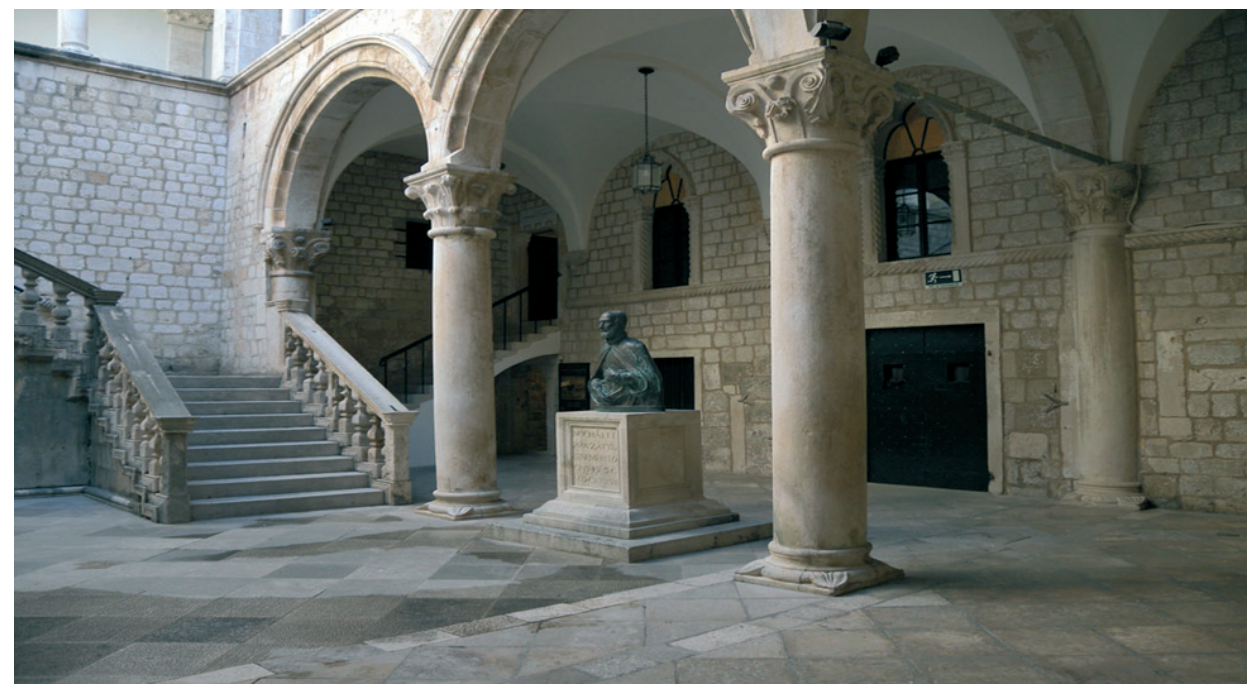

Slika 1. Istočni dio atrija Kneževa dvora

27 Andreis, Povijest hrvatske, 40.: Zvučnim signalom naviještali su početak rada, noćne uzbune, započinjanje svečanih priredbi, otvaranje i zatvaranje gradskih vrata i sl.

28 Isto: Najačešće su trubači i puhači bili angažirani u pojedinim svečanijim prilikama koje su zahtijevale formiranje većega sviračkog ansambla. 
Važno je spomenuti da je stalna plaća glazbenika određena tek nakon probnoga perioda u kojem je utvrđena razina njihovih glazbenih sposobnosti. Unatoč toj činjenici, možemo zaključiti da su glazbenici koji su djelovali u stalnoj službi Kneževe kapele imali relativno dobra novčana primanja. Oni su također imali priliku ostvariti dodatne prihode održavajući glazbene poduke iz sviranja, izrađujući glazbene instrumente, baveći se nekakvim drugim obrtom ${ }^{29}$ te svirajući u kakvim privatnim aranžmanima, ${ }^{30}$ prilikom crkvenih svečanosti ili gostovanja izvan granica Republike. Što se tiče samoga radnog vijeka glazbenika, on je varirao od kraćih perioda pa sve do pedeset godina službovanja. ${ }^{31}$

\section{Scenska glazba}

U Dubrovniku je također bio veoma razvijen i kazališni život čiji su nositelji bili glumci amateri okupljeni u družine. ${ }^{32} \mathrm{~S}$ obzirom na to da su kazališne predstave često objedinjavale scenski pokret i glazbu, u izvedbe su također bili uključeni i glazbenici Kneževe kapele. U Gradu su se izvodili svi renesansno-barokni scenski oblici: crkvena prikazanja, pastirske igre, tragedije, komedije, maskerate, jeđupke, pjesme od kola, melodrame i opere.

U Dubrovniku su sačuvana crkvena prikazanja Mavra Vetranovića Od poroda Jezusova, Posvetilište Abramovo i Suzana čista koja sadrže glazbene reference. Tako npr. u Posvetilištu Abramovu nailazimo na upute za pjevače: „počeše pastiri svirati i pojati.” Iz crkvenih prikazanja glazba je prenesena i u pastirsku igru koja u Dubrovniku doživljava procvat pojavom četiriju komedija Nikole Nalješkovića te pet drama Marina Držića. Početkom 16. stoljeća u Dubrovniku su se izvodili i prijevodi grčkih tragedija u kojima je bila istaknuta uloga zbora. Od njih su sačuvane Držićeva Hekuba, Zlatarićeva Elektra i Bunićeva Jokasta. Među komediografsko-dramskim radovima koji su izvođeni drugom polovicom 16. stoljeća u Dubrovniku ističu se djela Nikole Nalješkovića, Marina Držića i Antuna Sasina. Tako u djelu Antuna Sasina Flora

29 Demović, Glazba i glazbenici, 98-100.: Primjerice, Filip iz Drivasta bavio i izradom instrumenata, noževa, zastavica te drugim vrstama obrta koji su bili potrebni Republici, Blasius Tubicen također je radio kao postolar, Gabriel de Arimino kao zdur, gostioničar, te uzgajatelj sokola, Petercinus Piffarus kao bombardijer te Andreas Soldatus kao liječnik. Isto: Svirali su na krštenjima, svadbama, privatnim zabavama plemića i sl.

31 Andreis, Povijest hrvatske, 40.; Demović, Glazba i glazbenici, 90-140.

32 Demović, Glazba i glazbenici, 143-144.: Mladež je od djetinjstva u okviru svoga staleža i uzrasta bila okupljena u družine radi poštene zabave, bolje izobrazbe i ugodnijega življenja. 
uočavamo didaskalije koje upućuju na sudjelovanje pjevača, plesača i svirača u izvedbi djela: „Ovdi Milat počne pod vijolun začinat ovu pjesan." ${ }^{33} \mathrm{Na}$ glazbene didaskalije koje upućuju na to da su se dramska djela uprizoravala uz sviranje, pjevanje i plesanje nailazimo i u više Držićevih djela. Tako npr. u komediji Venera i Adon nailazimo na više takvih didaskalija: „Ovdi se odkrije šena. Vlasi se pripadu, a ukažu se šes vila, koje najprvo poju, pak tancaju;" „Svršivši pjesni i tanac, klanjajući se Veneri odhode, a Venere božica, užežena od ljubavi svoga Adona, tužeći se govori;” "Opet se odkrije šena i satir s vilom tanca." U Noveli od Stanca također se spominje plesanje tanca: „Ovdi tanac vode, pak vile govore," dok se u Grižuli pojavljuju didaskalije koje upućuju na pjevanje: „Za ovjezijem se muzika kanta." ${ }^{4}$

Maskerate, koje su u cijelosti pjevane kao i crkvena prikazanja, u Dubrovniku su uživale veliku popularnost o čemu svjedoči i njihova brojnost. Izvodile su se tako Jeđupka Mikše Pelegrinovića, Dobri Vrač Džore Držića; Dvije robinjice, Trgovci Armeni i Indiani, Lanci Alemani trumbaturi i pifari Mavra Vetranovića; Nagi Vrag, Vrag s mijehom, Vrag sa srcem, Sužnji, Prosjaci, Pastiri, Pastiri od Bobana, Putujući pjevači, Dokoni mladići, Sluge od ljubavi, Zaljubljenik i Poziv u kolo Nikole Nalješkovića, Vrtlari i Mužika od crevljara Antuna Sasina, Jeđupka te Majka Venere ište Kupida Sabe Mištića Bobaljevića, Jeđupka Horacija Mažibradića. Osobito je istaknut značaj Jeđupki koje su se izvodile uz sviranje različitih instrumenata (poglavito lutnje, citare i viole) i pjevanje zbora. 0 njihovu izvođenju svjedoči arhivski podatak iz sudskoga zapisnika Lamenta de intus iz 1580. godine o saslušanju jedne dubrovačke družine koja je tijekom godine po dubrovačkim ulicama uz pratnju lutnje, citru, violinu i mnoge druge instrumente pjevala lascivne i proste popijevke. Članovi družine branili su se govoreći da su izvodili samo pristojne popijevke i neke „moderne” pjesme među kojima su bile i one na stihove poznate maskerate Jeđupke. ${ }^{35}$

Pjesma od kola bila je još jedna omiljena i razgranata glazbena forma u Dubrovniku. Tu vrstu pjesama pisao je Nikola Dimitrović, no nažalost, njegova je ostavština izgubljena. Sačuvane su pak neke kraće pjesme Din-

33 Leksikon Marina Držića. Preuzeto s: http://leksikon.muzej-marindrzic.eu/glazba/ (20. 7. 2017.)

34 Demović, „Glazba u renesansnom Dubrovniku.” Dani Hvarskoga kazališta: Građa i rasprave o hrvatskoj književnosti i kazalištu 14/1 (1988): https://hrcak.srce.hr/file/152541 (srpanj 2017.).

35 Demović, Glazba i glazbenici, 160-167.: Operu Euridice prevodi Paskoje Primović, ali ne iz libreta nego iz glazbene partiture što zaključujemo zbog sadržanih didaskalija vezanih za zbor. 
ka Ranjine te pjesme Junija Palmotića s početka 17. stoljeća. Zabilježeni su i podaci o izvođenju melodrama i opera u Dubrovniku, i to neposredno nakon njihovih praizvedbi u Italiji kao npr. Euridice ${ }^{36}$ i Arianne. Pripremanje izvedbe opere, tog velikoga glazbeno-dramsko-scenskog projekta, zasigurno je iziskivalo velike pripreme te veliku umjetničku sposobnost glazbenika koji su djelovali u Dubrovniku početkom 17. stoljeća. ${ }^{37}$

\section{Dubrovački renesansni instrumentarij}

$\mathrm{U}$ dubrovačkom instrumentariju, ${ }^{38}$ najstariji je spomen trube ${ }^{39} \mathrm{i}$ bubnja. ${ }^{40}$ Ostali instrumenti pojedinačno se spominju tek od polovice 14. stoljeća: zaramela, kornet, harfa, lutnja, orgulje i trombon. Zanimljiv je i podatak o postojanju instrumenata Dulcimera (dulce melos) i organistruma iz 1443. godine, instrumenata za koje Republika u to vrijeme nije mogla pronaći kvalificirane svirače. Među instrumentima zastupljenima u narodnoj glazbi potrebno je spomenuti leut tj. lijericu, mješnicu te gusle.0 orguljama, upravo zbog njihove veličine i značaja u crkvenoj glazbi, imamo malo više sačuvanih informacija. Najstariji sačuvani podatak o njihovom postojanju u Gradu sadržan je u zapisniku Maloga vijeća iz 1384. godine. Iz istoga izvora saznajemo i da je u drugoj polovici 14. stoljeća u Dubrovniku postojalo više orgulja. ${ }^{41}$ Vijeće najprije odobrava blagajnicima stolne crkve svete Marije nabavu orgulja u vrijednosti od 100 zlatnih dukata, a četiri godine kasnije u katedrali nailazimo na spomen još dvaju orgulja manjih dimenzija. Krajem 15. stoljeća postojale su orgulje i u crkvi svetoga Vlaha. ${ }^{42}$

Iako su navedeni instrumenti u Dubrovnik pretežito stizali iz Venecije, u izvorima također nailazimo i na podatke o domaćoj izradi instru-

36 Demović, Glazba i glazbenici, 143-167.; Demović, „Glazba u renesansnom.”; Leksikon Marina Držića. Preuzeto s: http://leksikon.muzej-marindrzic.eu/glazba/ (20. 7. 2017.)

37 Isto, 132-133.: Ukupnost glazbenih instrumenata koji se koriste u skladbama određene glazbene epohe ili u nekom određenom periodu.

38 Isto, 132-133.: Spominje se od samoga početka postojanja Kneževe kape pod raznim nazivima: trombetta, trombecta, tubecta i tuba. (Demović, Glazba i glazbenici, 132-133.)

39 Isto: Susreće se pod nazivima taburelo, tamburelo, tamburino i sl. (Demović, Glazba $i$ glazbenici, 132-133.)

40 Isto: Susreće se pod nazivima taburelo, tamburelo, tamburino i sl. (Demović, Glazba i glazbenici, 132-133.)

41 Isto, 46-57.: U katedrali, u crkvi svetoga Vlaha, u samostanskoj crkvi sestara klarisa te kasnije u privatnom vlasništvu.

42 Kos, „Muzički instrumenti,” 197-199.: O postojanju orgulja u crkvi svetoga Vlaha svjedoči nam ugovor sklopljen 1493. godine između dubrovačke vlade i Pelegrina iz Riminija koji postaje novi orguljaš u toj crkvi. 
menata. Tako se npr. spominju glazbenici Barnaba Pifarus te trubač Filip iz Drivasta ${ }^{43}$ koji su se osim izvodilačkom praksom bavili i izradom instrumenata. Dubrovački glazbenici su u svom privatnom vlasništvu najčešće imali jedan ili više instrumenata koje su znali svirati. ${ }^{44}$

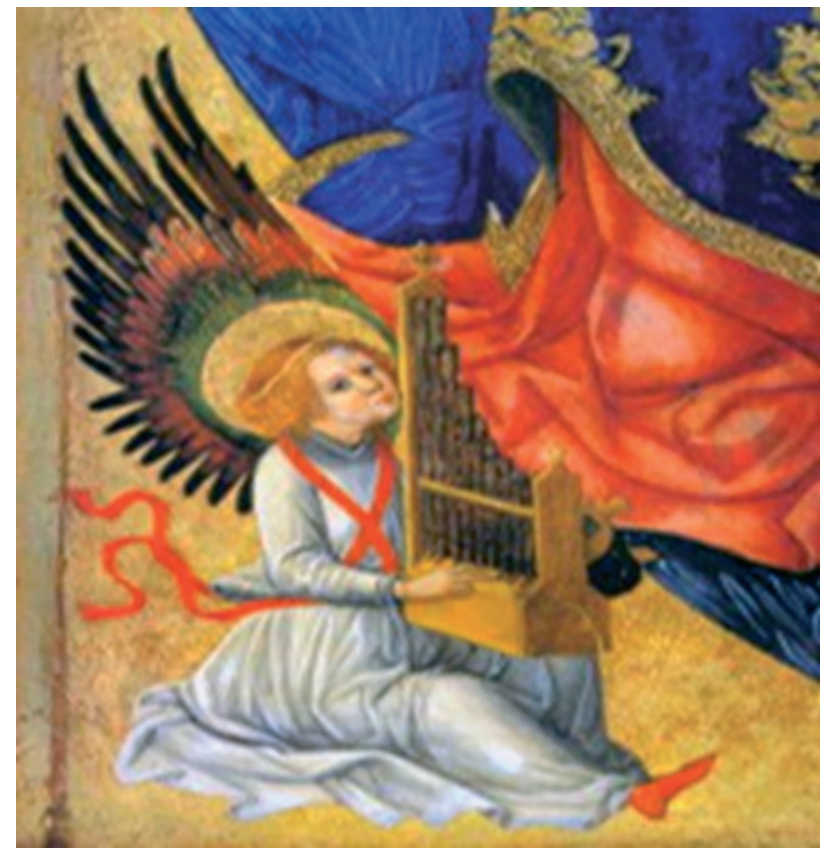

Slika 2. Lovro Matinov Dobričević, lik anđela na poliptihu iz 1465. godine

\section{Stjecanje glazbenoga obrazovanja}

Iako se velik broj dubrovačkih glazbenika školovao na glazbenim sveučilištima u Italiji, osnovna glazbena poduka mogla se primiti i u Gradu. Poduka iz osnova glazbene teorije, pjevanja i sviranja orgulja mogla se primiti od klerika ${ }^{45}$ dok su privatne poduke iz sviranja ostalih instrumenata osiguravali glazbenici Kneževe kapele. Tako npr. nailazimo na Petrusa Bodona, reproduktivnoga glazbenika koji u Dubrovnik dolazi s dvora burgundskoga vojvode, koji se, uz sviranje, ba-

43 Demović, Glazba i glazbenici, 90-93.: Proizveo je instrument dulcimer (dulce melos).

44 Isto, 46-57., 90-93., 132-133.; Demović, „Glazba u renesansnom.”; Kos, „Muzički instrumenti," 197-199., 233-235.

45 Isto, 96.: Klerici su također održavali poduke iz svjetovne glazbe. 0 tome nam svjedoči i podatak o dvojici dubrovačkih orguljaša Ivanu Kristoviću i Petru Tominom iz 1573. godine koji su u crkvi, uz crkvenu glazbu izvodili i plesnu glazbu (gagliarde, saltareli, pasameci, pavane, bali di torce i dr. plesove). 
vio i pedagoškom djelatnošću. Možemo pretpostaviti i da je Georgius ab Arpa, obrazovan i reproduktivan glazbenik davao glazbene poduke u sviranju leuta i harfe. Ipak, uočavamo da su najznačajniji doprinos dubrovačkoj renesansnoj odgojno-pedagoškoj, ali i reproduktivnoumjetničkoj te skladateljskoj djelatnosti ostvarili svojim djelovanjem trojica glazbenika iz obitelji Courtois.

Glazbeno znanje moglo se prenositi i unutar obitelji s koljena na koljeno. U tom pogledu možemo spomenuti glazbenike iz obitelji Costich (Costu, njegova sina Jakoba i unuka Tomu) koji su kroz tri generacije djelovali pri Kneževoj kapeli kao svirači puhačkih instrumenata. Naposljetku, glazbenici su također mogli uzimati talentirane mlade ljude za svoje naučnike te ih podučavati glazbenom umijeću. Glazbenici su vjerojatno imali i osobne priručne zbirke tiskanih muzikalija koje su također mogli koristili prilikom poduka. ${ }^{46}$

\section{Podrijetlo glazbenika}

U Dubrovniku je, uz mnoštvo domaćih glazbenika, također djelovao i značajan broj glazbenika stranoga podrijetla. Najveći broj stranih glazbenika koji su djelovali u Kneževoj kapeli potjecao je iz Italije. U dubrovačkim se arhivskim dokumentima u razdoblju između 1378. i 1558. godine također pojavljuje desetak imena glazbenika s njemačkoga govornog područja. ${ }^{47}$ Među glazbenicima stranoga podrijetla spominju se i oni podrijetlom iz Grčke, ${ }^{48}$ Španjolske ${ }^{49}$ i Albanije. Najznačajniji utjecaj na dubrovačku renesansu glazbu ipak su ostvarili glazbenici franko-flamanskoga podrijetla. ${ }^{50} \mathrm{U}$ tom pogledu osobito su se istaknuli članovi obitelji Courtois. ${ }^{51}$

46 Demović, Glazba i glazbenici, 84., 90-99., 107-114.

47 Isto, 74.: Helias Theutonicus, Juanis Theutonicus, Radasinus Theutonicus, Petecrinus Allemanus, Pater Noster de Prusa, Petrus de Collonia, Matheus de Zanpizolo i Petrus Germanus.

48 Demović, „Glazba u renesansnom.”: Tomasius de Candia, Georgius Gralus de Candia, Theodorus de Arta, Johannes de Arta, Antonius Grecus, Marchus Grecus, Laurentius Manes i Aloysius Manes. Od svih glazbenika grčkoga podrijetla najznačajniji je Laurentius Manes.

49 Isto: Gregorius de Medina.

50 Isto: Gallus Piffarus, Petar Francigena te trojica članova obitelji Courtois.

51 Demović, Glazba i glazbenici, 74.;

Demović, „Glazba u renesansnom." 


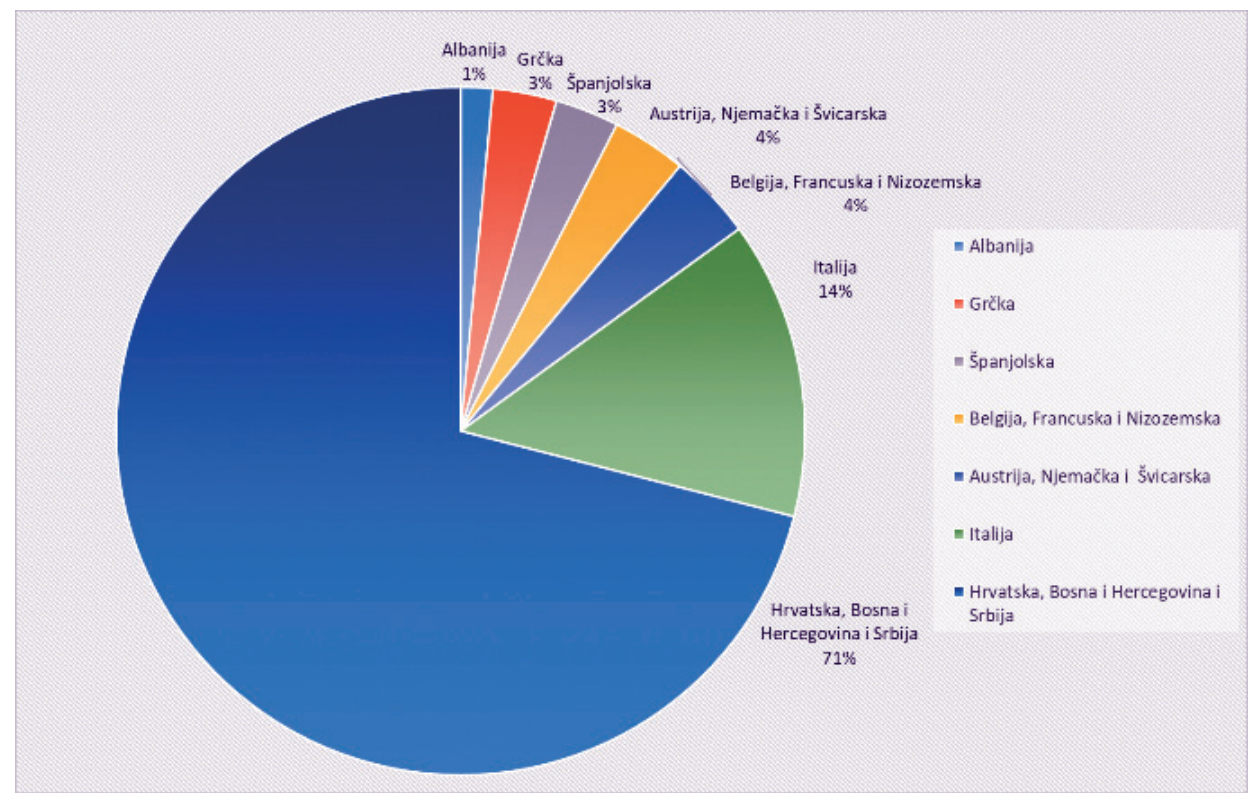

Slika 3. Grafički prikaz glazbenika koji su djelovali u Kneževoj kapeli od 1400. do 1600. godine prema zemlji njihova podrijetla

\section{Glazbenici koji su djelovali u Dubrovniku u 15. i 16. stoljeću.}

Od notara Kneževe kapele saznajemo imena prvih glazbenika koji su djelovali u Dubrovniku te osnovne podatke o njima. Prvi spomen imena nekoga glazbenika u Dubrovniku poimence potječe iz 1302 . godine kada se spominje trubač Matheus Preco. Nedugo zatim zabilježena su imena i podaci o trubačima glasonošama Niccoli Mathie de Pontignanu i Angelusu de Nei. Jureč iz Brinja u Lici i Benčo Ivanišević, koji su djelovali u Dubrovniku koncem 14. stoljeća, prvi su poimence zabilježeni glazbenici podrijetlom iz hrvatskih gradova. Broj glazbenika domaćega podrijetla kasnije se umnaža što potvrđuje spomen Ostoje Pifarusa te Vochmira Sonatora i Fratera Zlatonoschicha te još nekolicine glazbenika pristiglih s bosanskoga velikaškog dvora. ${ }^{52}$

Među značajnijim imenima dubrovačke glazbe ovoga razdoblja pojavljuje se Marin Držić, jedan od najznačajnijih hrvatskih dramatičara. Iako se prvenstveno bavio književnim radom, poznato je da je bio i glazbenik praktičar. Naime, prema odluci Velikoga vijeća, Držić je imenovan katedralnim orguljašem 28. veljače 1538. godine za što je

52 Demović, Glazba i glazbenici, 74. 
primao plaću od sto perpera godišnje. Osim umijeća sviranja orgulja, Jeronim Vlahov Držić u obiteljskoj genealogiji tvrdi da je Držić također svirao i na mnogobrojne druge instrumente. ${ }^{53}$ To nam potvrđuje nadgrobnica Na priminutje Marina Držića Dubrovčanina koju piše pjesnik Mavro Vetranović prigodom Držićeve smrti 1567. godine:

„plačni su leuti i tužni ostali,

nijemi su flauti i ostali svirali,

smetel je violune taj čemer nemili,

da slatko ne zvone kako su zvonili."

Pjesma upućuje na to da je Držić znao svirati leut, flautu, violune, ${ }^{54}$ kordinu, kornet, klavičembalo i orgulje. S obzirom na to da je 1538. godine osam mjeseci bio orguljaš dubrovačke stolnice te se dodatno školovao za zvanje glazbenika u Sieni, pretpostavlja se da je Držić imao dovoljno glazbenoga znanja za samostalno skladanje glazbenih brojeva za svoja scenska djela. Milan Rešetar u svom radu Djela Marina Držića ističe pojedine Držićeve drame u kojima se pojavljuju glazbene reference. Uočava da su u Mandi sadržana dva vokalna broja, u Dundu Maroju jedna talijanska kanconeta, u Veneri i Adonu jedan vokalni i dva plesna broja, u Noveli od Stanca jedan plesni broj te u Grižuli jedan broj orkestralnoga karaktera. Lovro Županović primjećuje da i u Hekubi ima nekoliko didaskalija koje upućuju na instrumentalno muziciranje u okviru scenske izvedbe djela. Dok je glazbeni broj iz Dunda Maroja očito preuzeo iz jedne talijanske melodije, ostale vokalne i instrumentalne ulomke mogao je skladati i sam Držić.

Secondo Brugnoli još je jedan dubrovački glazbenik koji potječe iz ugledne talijanske obitelji koja se prvom polovicom 15. stoljeća doselila u Grad. Od mladih dana bavio se glazbom i pomorskom trgovinom, a nakon što se zaredio i postao svećenikom njegovo glazbeno djelovanje se intenziviralo. Zabilježeno je da je ispjevao i skladao više pjesama, obrađivao višeglasno crkvene himne te napisao pouku o koralnom pjevanju.

Gavro Temparičićs ${ }^{55}$ dubrovački je franjevac koji se ujedno bavio i glazbom. Glazbeno obrazovanje primio je u Italiji, a potom je velik dio svoga života proveo u Beču gdje je, prema Crijevićevoj Bibliotheci, zbog svoje iznimne vještosti u glazbenoj umjetnosti, djelovao kao dvorski

53 Leksikon Marina Držića. Preuzeto s: http://leksikon.muzej-marindrzic.eu/glazba/ (20. 7. 2017.): „Era musico eccelentiss[im]o et sonaua d'ogni sorte de instrumenti” (u prijevodu: „Povrh toga bio je i izvrstan glazbenik te je svirao na svim vrstama glazbala”).

54 Lovro Županović, Stoljeća hrvatske glazbe, Zagreb, 1980., 48-50.: gudački kontrabas.

55 Andreis, Povijest hrvatske, IV., 42.: Nailazimo i na inačice prezimena Tamparica, Temparricus. 
učitelj glazbe i glazbeni ravnatelj na dvoru cara Matije. Iako je mnogo vjerojatnije da je služio kod Matije dok je bio nadvojvoda te podučavao nekoga od članova carske obitelji glazbi.

Benedikt Babić još je jedan istaknuti dubrovački glazbenik koji se školovao u Italiji. Glazbeno obrazovanje stekao je u Bologni, a potom se bavio podučavanjem glazbe u Dubrovniku i još nekim talijanskim gradovima. Dok ga Serafin Razzi spominje kao glazbenika i orguljaša, Ambrozije Gučetić Gozze navodi da je bio nastavnik glazbe, prvi među orguljašima te autor mnogih glazbenih djela. Također se u izvorima spominje da je vrlo dobro poznavao glazbu i pjevao, te svirao i gradio orgulje. Slade Dolci u svojoj Dubrovačkoj književnoj kronici ${ }^{56}$ navodi da je Babić prvi koji uvodi koralno pjevanje u svoje skladbe. Navodno je za sobom ostavio i nekoliko rasprava o glazbi. ${ }^{57}$

\section{Istaknuti glazbenici stranoga podrijetla}

\section{Članovi obitelj Courtois}

U ovom kontekstu valjalo bi posebno istaknuti trojicu glazbenika iz obitelji franko-flamanskoga podrijetla koji su se u renesansnom i baroknom razdoblju osobito istaknuli svojom glazbenom, skladateljskom i pedagoškom djelatnošću u Dubrovačkoj Republici. To su bili Lambert Courtois Stariji i njegov sin Henrik, obojica djelatna kao maestri di cappella, te Lambertov unuk Lambert Mlađi. Ova trojica glazbenika iz obitelji Courtois uspješno su zadržala obiteljski monopol nad položajem ravnanja Kneževom kapelom glazbenika više od sto godina. Lambert Stariji djelovao je u Dubrovniku od 1554. do 1570. godine. Na njegovu se mjestu u Kneževoj kapeli uskoro našao i njegov sin Henrik koji je ondje djelovao u razdoblju od 1573. do 1629. godine. Lambert Mlađi, Henrikov sin, rođen je u Dubrovniku gdje je i umro 1664. godine. On je također nastavio s obiteljskom tradicijom te je djelovao u Kneževoj kapeli u baroknom razdoblju. Pripadnici ove obitelji istaknuli su se i svojom skladateljskom djelatnošću."58

56 Andreis, Povijest hrvatske glazbe, IV., 43.: Fasti litterario - Ragusini sive virorum litteratorum Qui usque ad annum MDCCLXVI in Ragusina claruerunt Ditione, 1767.

57 Isto, 42-43.; Demović, Glazba i glazbenici, 56., 71-78., 89., 277.; Stipčević, „Dominikanci i glazba." Preuzeto s: https://hrcak.srce.hr/74297 (13. 8. 2018.); Županović, Stoljeća hrvatske, 48-50.

58 Demović, Glazba i glazbenici, 107. 


\section{Laurentius Manes}

Još se jedan glazbenik stranoga podrijetla u Dubrovniku istaknuo svojim glazbenim sposobnostima. Laurentius Manes bio je podrijetlom Grk, a kao glazbenik Kneževe kapele djelovao je od otprilike 1504. pa sve do 1539. godine kad se u oporuci svoje bivše sluškinje spominje kao pokojni. Pokazao se kao iznimno sposoban trombonist zbog čega je uživao velik ugled u Gradu, a o tome svjedoče i podaci o njegovoj pobjedi na natjecanju svirača. Njegov nadimak bio je Saraceno ili Negro što je upućivalo na njegovu tamnoputost. Upravo zbog toga nadimka Demović ga povezuje s imenom Machetta Care čije su brojne skladbe sačuvane i tiskane u Petruccijevim zbirkama Frottola. ${ }^{59}$

\section{Sačuvana notna građa}

Možemo reći da je dubrovačka skladateljska baština iz pretpotresnoga razdoblja veoma siromašna jer sadržava samo nekolicinu sačuvanih fragmentarnih ulomaka gregorijanskih korala, ${ }^{60}$ nekoliko renesansnih skladbi Lamberta Starijeg Courtoisa te ranobaroknih skladbi Vincenza Komnena. Ipak, možemo pretpostaviti da je dio lirske poezije dubrovačkih renesansnih pjesnika također bio uglazbljen te da su skladani i glazbeni brojevi za određena scenska djela. Možemo pretpostaviti da skladateljsko stvaralaštvo nije bilo usmjereno isključivo na produkciju tekstova na latinskom jeziku za potrebe bogoslužja ili na pjesničke sastave talijanskoga i hrvatskoga podrijetla za prigode svjetovnoga zabavljanja, nego i na skladanje instrumentalnih komada za različite potrebe orkestralnoga muziciranja poput koračnica, budnica, povečerja, plesne glazbe itd. S obzirom na to da ovi notni predlošci nisu sačuvani, o samoj notnoj građi i njezinoj umjetničkoj vrijednosti nažalost ne možemo suditi.

Nastavak rada donosi kratak pregled i analizu sačuvanoga skladateljskog opusa Lamberta Courtoisa Starijega i Vincenza Komnena. ${ }^{61}$

59 Demović, „Glazba u renesansnom.”

60 Isto: Od 10. do 12. stoljeća sačuvano je 25 notnih predložaka, a od 13. do 17. stoljeća 40 notnih predložaka u kvadratnoj notaciji.

61 J. Andreis, Povijest hrvatske glazbe, 12-14.; M. Demović, „Dubrovački ranobarokni skladatelj Vicenco Komnen (1560.-1667.)”, Rad, 377 (1978), 315-336., Preuzeto s: https:// dizbi.hazu.hr/object/10840

Demović, „Glazba u renesansnom.” Preuzeto s: https://hrcak.srce.hr/file/152541 (5. 7. 2017.) 


\section{Skladateljski opus Lamberta Starijega i Henrika Courtoisa}

Madrigali Lamberta Courtoisa Starijega i njegova sina Henrika jedini su sačuvani primjerci dubrovačkoga renesansnog skladateljstva. Fragmentarno sačuvani skladateljski opus Lamberta Starijega nastaje tijekom njegova boravka u Dubrovniku, a obuhvaća osamnaest svjetovnih i šest duhovnih madrigala te jednu instrumentalnu kanconu. ${ }^{62}$ Njegov prvi madrigal tiskan je 1562. godine pod naslovom Perche crudel amor, a već sljedeće godine objavljuje šest novih madrigala duhovne tematike. Duhovni madrigali tematski obrađuju muku Kristovu, a skladani su tako da se svaki madrigal može izvoditi samostalno ili kao dio cjeline s ostalima. Melodijske linije madrigala građene su dijatonski ${ }^{63}$ nizanjem visinski bliskih intervala zbog čega skladbe odišu jednostavnošću i mirnoćom. Ravnomjerna izmjena polifonoga i homofonoga sloga omogućuje razumijevanje ciklički građenoga duhovnog teksta. $^{64}$

Jedina Lambertova sačuvana instrumentalna skladba preradba je francuske kancone Petit Jacquet. Skladba je tiskana 1577. godine i pretpostavlja se da je stvorena isključivo za potrebe dubrovačkih svirača. Koliko je ova skladba bila bitna za instrumentalnu praksu svoga doba, govori nam i činjenica da je ponovno tiskana kao dio priručnika za instrumentalnu glazbu. ${ }^{65}$

Krunu Lambertova stvaralaštva predstavlja samostalna zbirka s osamnaest peteroglasnih madrigala svjetovne tematike objavljena 1580. godine. U zbirci se nalaze i dva madrigala koje je skladao Lambertov sin Henrik. Unatoč činjenici da dionice gornjih glasova (soprana i alta) nisu sačuvane te zbog toga ne možemo procijeniti pravu vrijednost Lambertovih i Henrikovih madrigala, ova zbirka je od izuzetne kulturno-povijesne vrijednosti za Dubrovnik jer je spjevana u čast dubrovačkih plemića Miha Bunića, Nikole Gundulića i Marka Basiljevića. Zbirka započinje s tri madrigala skladana u pohvalu Grada, Tra i duri

62 M. Demović, Glazba i glazbenici, 115-128.; Danas su u cijelosti sačuvani samo duhovni madrigali i instrumentalna kancona.

63 Isto: Osim dijatonike, u madrigalima nailazimo na povremenu pojavu kromatike što je tipično za skladbe nastale u razdoblju kasne renesanse.

64 Isto: U madrigalima se kreće od pojedinačnih opisa dijelova tijela (ruku i nogu) te se naposljetku dolazi do opisa probodena srca te izmučena tijela Kristova.

65 Leksikografski zavod Miroslav Krleža, Preuzeto s: http://hbl.lzmk.hr/clanak. aspx?id=3698_(7. 8. 2017.): Priručnik Girolama Dalla Case Il vero modo di diminuir (1584) obrađuje različite načine instrumentalnoga ornamentiranja uz obogaćivanje teorijskoga znanja primjerima skladbi tadašnjih najuglednijih skladatelja. 
scogli u kojem skladatelj veliča kulturne vrednote Dubrovnika, Comun novel Parnasso u kojem se ističe veličina pjesnika Miha Bunića i njegovih prijatelja Nikole Gundulića i Marka Basiljevića te Locar Sovra gli abissi u kojem se hvali dubrovačka klima. ${ }^{66}$

\section{Skladateljski opus Vincenza Komnena}

Vincenzo Komnen (1590. - 1667.) još je jedan stariji dubrovački skladatelj čija je glazbena ostavština sačuvana do danas. Njegovo stvaralaštvo izlazi iz okvira 15. i 16. stoljeća i zalazi u razdoblje ranoga baroka, ali je značajno jer svjedoči o živoj povezanosti Dubrovačke Republike s aktualnim glazbenim trendovima u Italiji.

Do danas su sačuvana tri Komenova barokna madrigala skladana na isti tekst povodom vjenčanja Marije Ane Austrijske (1634. - 1696.) i Filipa IV. (1605. - 1665.). Naslov madrigala aludira na sreću grada Napulja, ${ }^{67}$ sreću koja dolazi španjolskom vladaru u liku dostojne žene suvladarice. Prvi madrigal napisan je za visoki glas i basso continuo te je građen u obliku pitanja i odgovora. ${ }^{68} \mathrm{U}$ njemu se isprepliću kratki motorični i lepršavi motivi. Drugi madrigal je dvoglasan i mirnijega karaktera, a građen je kao mješavina homofonoga i polifonoga sloga. U njemu se osjeća utjecaj narodne melodike. Treći homofoni madrigal pisan je za mješoviti troglasni zbor te u njemu umjetnička zrelost skladatelja dolazi do punoga izražaja. ${ }^{69}$

66 Demović, Glazba i glazbenici, 107-128.; Leksikografski zavod Miroslav Krleža. Preuzeto s: http://hbl.lzmk.hr/clanak.aspx?id=3698 (7. 8. 2017.)

67 Demović, „Dubrovački ranobarokni”: Partenopa, grčka sirena, legendarna je osnivačica Napulja.

68 Isto: Ležeći basov ton.

69 Demović, „Dubrovački ranobarokni.” Preuzeto s: https://dizbi.hazu.hr/object/10840 (2. 8. 2018.); Tuskar, „Dubrovački ranobarokni.” Preuzeto s: http://hrcak.srce.hr/ file/211888 (3. 9. 2017.); Demović, Glazba i glazbenici, 58-60. 


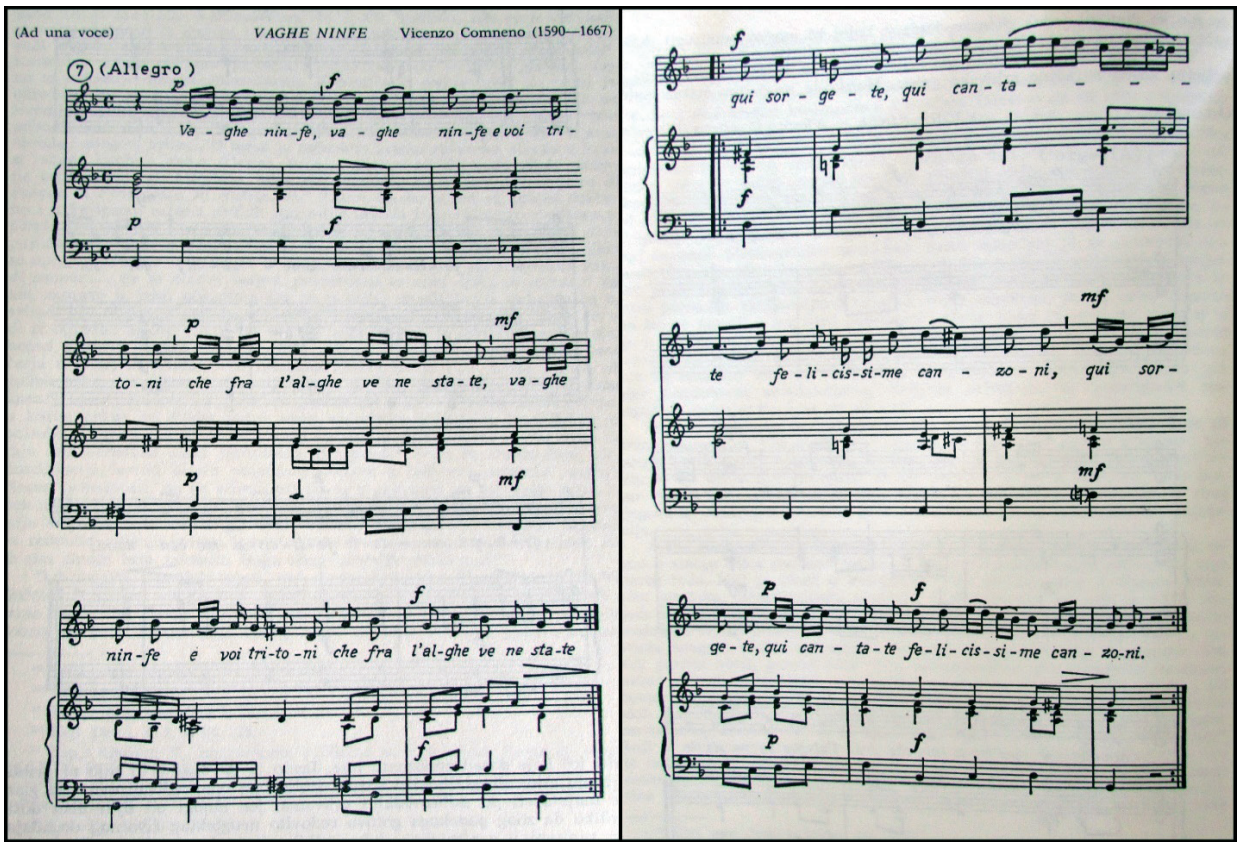

Slika 4. Notni predložak skladbe Vaghe ninfe

\section{Prilike za muziciranje}

Glazbeni život renesansnoga Dubrovnika bio je veoma bogat. Uz muziciranja crkvenih pjevača te djelovanja profesionalnoga glazbenog ansambla Kneževe kapele, glazbu su također izvodile omladinske glazbene družine, amateri te folklorni pjevači i svirači. Prilike za muziciranje bile su brojne, a glazba se izvodila na Kneževom dvoru, u palačama plemića, u kućama na ulici i u crkvama.

Veoma je značajna bila uloga glazbe u državnom ceremonijalu. Gotovo svi državni rituali bili su javni te su održavani na simboličnim gradskim lokacijama ${ }^{70}$ uz nazočnost mnogobrojne publike. Glazba je u tome imala važnu funkcionalnu i umjetničku ulogu kao sredstvo naglašavanja i zaokruživanja državnih obreda prikazujući tako sav sjaj i moć Republike. Svaki javni ritual bila je visokostilizirana izvedba u kojemu je do posebnoga izražaja dolazila funkcionalna uloga glazbe. U Dubrovniku su javni rituali izvođeni u nekoliko tipičnih formi. Prva

70 Nella Lonza, Kazalište vlasti. Ceremonijal i državni blagdani Dubrovačke Republike u 17. i 18. stoljeću, Dubrovnik, 2009., 443-444.: Svaka gradska lokacija imala je svoju težinu i značenje. 
forma u kojoj su predstavnici vlasti sjedili pod trijemom Kneževa dvora i promatrali neko zbivanje bila je statična. Nasuprot tome, druga forma uključivala je pokret, nekakvu vrstu procesije, mimohoda ili ophodnje. ${ }^{71}$ Gotovo uvijek je mjesto polaska bio Knežev dvor te se nastavljalo prema nekom crkvenom objektu ili kružilo središnjim gradskim prostorom.

Funkcionalna uloga glazbe posebno se isticala u povezanosti glazbenika Kneževe kapele s likom kneza. Naime, glazbenici puhači bili su u njegovoj stalnoj pratnji te su pratili svaki knežev izlazak s Dvora. Banda del Principe, koju je u 18. stoljeću sačinjavalo nekoliko puhača, oboista i fagotista, uveličavala je svojom svirkom i pojave državnih poglavara na javnim događanjima. Vlada je također određivala profesionalnim glazbenicima da javno izvode serenade i matinate uglednim građanima. Tako je primjerice 1446. godine bogataš Simon Allegretti uživao u izvedbama serenada svake subote pod svojim prozorom. To je zapravo bio iskaz kneževe posebne zahvalnosti što je Republiku pomogao velikim iznosom novca. Iako su kneževi glazbenici ponekad izvodili složenije glazbene forme, najčešće su se ipak svirali kratki i nemaštoviti komadi prikladni javnim događajima ili jednostavne koračnice.

Osim toga, glazba je pridonosila i dramatičnosti događaja označavajući početak i kraj svakoga javnog rituala. Tako se npr. topovskim pucnjevima i prigodnom glazbom iskazivala počast uglednim gostima, a zvonjava zvona obznanjivala je smrt kneza. Svirka je pratila i prigodnu svečanost blagoslova i postavljanja novih brodova u vodu u gruškom brodogradilištu. Naposljetku, glazbenici su obavljali i neugodnu dužnost praćenja čina smaknuća osuđenika. ${ }^{72}$

Značajno mjesto glazbenici su imali u proslavi važnih katoličkih blagdana u kojima su liturgijska pravila bila nad državnim ceremonijalom. Crkveni bi glazbenici u tim prilikama na poseban način upriličili ulazak novoga nadbiskupa u grad pjevanjem svečanoga Te Deuma u katedrali. Najsvečanije misno slavlje odvijalo se tijekom božićnoga (razdoblje od Došašća do Svijećnice) i uskršnjega ciklusa, proslave zaštitnika grada svetoga Vlaha te marijanskih blagdana. ${ }^{73}$

71 Nella Lonza, Kazalište vlasti, 443-444.: Kao npr. pogrebi, sramotne ophodnje, javno izvođenje kazne, službeni izlasci kneza itd.

72 Demović, Glazba i glazbenici, 19-20.: Dužnost bubnjara bila je pratiti osuđenika u povorci od zatvora do mjesta stratišta te svirati nakon smaknuća.

73 Isto, 19-20., 135.; Kos, „Muzički instrumenti,” 238-242.; Lonza, Kazalište vlasti, 134140., 335., 443-444.; Primorac, Poj ljuveni, 83. 


\section{Blagdan svetoga Vlaha}

Razzi nam donosi opis crkvenih obreda prilikom proslave blagdana gradskoga patrona. On navodi kako je vjerska svetkovina počinjala na trodnevlje prije blagdana večernjom misom u crkvi svetoga Vlaha i panegirikom. Večer uoči blagdana svirka kneževih glazbenika ${ }^{74}$ pratila je kneza i ostale predstavnike vlasti ${ }^{75}$ od Dvora do katedrale gdje se izvodila svečana večernja misa koju su uveličavali pjevači iz redova franjevaca i dominikanaca izvodeći naizmjence koralne napjeve. Drugi dio mise uljepšavala je zborska polifona izvedba magnificata uz pratnju orkestra. Nakon svečane večernje slijedila je procesija u kojoj su pripadnici cehova i bratovština u skupinama prilazili oltaru te prinosili svoje darove crkvi i svecu. To darivanje je popraćeno glazbom dok je crkva obasjana samo svjetlom gorućih baklji. Procesija se završavala u sumrak nakon čega su se redovnici vraćali u svoje matične samostane sa svijećama u rukama i pjevajući Te Deum. Istovremeno s liturgijom koja se održavala u katedrali, u crkvi svetoga Vlaha također se održavala večernjica na kojoj se pjevala himan Parcu.

Sljedeće jutro, nakon mise u svojoj crkvi, dominikanci dolaze u procesiji do prvostolnice te, s franjevačkim svećenicima, postavljaju moći svetoga Vlaha na glavni oltar. Potom se procesija vraća u katedralu u kojoj se pjeva svečana misa na kojoj su se pjevale laude ${ }^{76}$ te obavljao blagoslov kruha. Pjevanje lauda bio je običaj koji se u Dubrovniku uvriježio od vremena bizantske vlasti te trajao sve do 18. stoljeća.

74 Demović, Glazba i glazbenici, 16.: Glazbenici su bili odjeveni u ista ceremonijalna državna odijela koja su nosili knez i malovijećnici.

75 Isto: Na misi su bili prisutni knez i Malo vijeće.

76 Isto, 14.: Nazivane i acclamationes. 

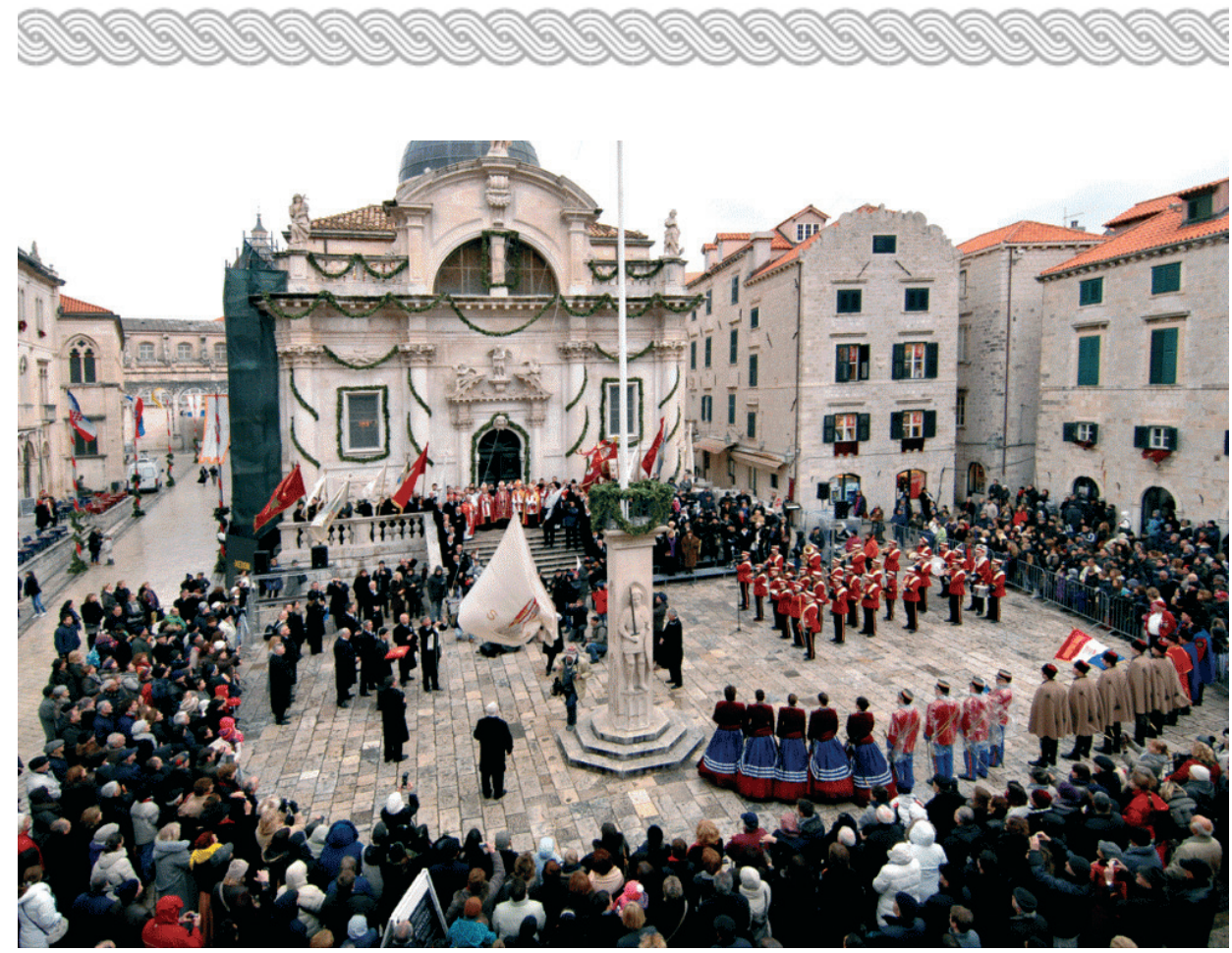

Slika 5. Procesija povodom Blagdana svetoga Vlaha u Dubrovniku

Njihovi su tekstovi tijekom vremena mijenjani jer su u sam sadržaj bili uključeni predstavnici i duhovne i svjetovne vlasti. Nakon mise fokus se prebacio pred Knežev dvor gdje su se nalazili knez i članovi Maloga vijeća okupljeni na klupici pod trijemom. S jedne strane odzvanjala bi svirka puhača, ${ }^{77}$ dok je s druge strane slijedio odgovor bubnjara svečanih četa. Ti prepoznatljivi zvukovi najavljivali su državnu vlast i odrede pod oružjem, dvije grupacije oko kojih se artikulirao važan dio proslave Svetoga Vlaha. Potom je uslijedila izvedba „plesa obilja," rustikalnoga plesa uz glazbu koji je izvodilo dvanaest starijih žena „tržnica." ${ }^{78}$ To je bio jedan od obrtničkih plesova koji su se izvodili u javnim prigodama i kojima je zajednica iskazivala koliko je zapravo važno i dostojno mjesto tih obrta u gradskoj socijalnoj strukturi. Nakon povorke praćene zvukom „slavenskih pjesama s prekrasnim napjevima" ${ }^{79}$ u kojoj je narod iz Dubrovnika i okolice ulazio u Grad noseći barjake te odjeven u slikovita odijela i naoružan različitim oružjem, uslijedio je zabavni program.

77 Demović, Glazba i glazbenici, 14.: Puhači su inače pratili reprezentativne državne događaje te su slani velikašima i dužnosnicima iz zaleđa da uveličavaju i njihove proslave svojom svirkom.

78 Isto: Žene koje su se bavile pečenjem kruha, pekarice.

79 Isto: Plaća im je znala iznositi i do 120 perpera. To je bila nagrada zbog toga što su svojim sudjelovanjem iskazali posebnu čast Republici te uveličali samu proslavu.) 
Zabavni dio svečanosti bio je bogato osmišljen, a u njemu su sudjelovali brojni domaći i strani glazbenici i plesači kojima je cilj bio zabaviti okupljeno mnoštvo iz grada i susjednih krajeva. Uz narodne pjevače i svirače iz Dubrovnika u slavlju su također sudjelovali profesionalni glazbenici iz Kneževe komore te pjevači, glazbenici i glumci s dvorova susjednih hercegovačkih i bosanskih vladara te putujući lakrdijaši. U Dubrovniku su upravo ti bosansko-hercegovački glazbenici uživali posebno gostoprimstvo prigodom svečanosti Svetog Vlaha koji su za svoje sudjelovanje u muziciranju tijekom ovoga blagdana bivali veoma dobro novčano nagrađeni. ${ }^{80}$ Ponekad je broj tih glazbenika bio poprilično v Dio zabavnoga programa činila su i natjecanja u raznim vojnim, plesnim i gimnastičkim vježbama. Tako Michael Quiclet navodi da su se 1658. godine na proslavi Svetoga Vlaha oko podne na trgu stražarnice odvijali plesovi seljaka, dok su u poslijepodnevnim satima građani i gradski vojnici izvodili vježbe nalik bitci pred palačom. Te vježbe bile su hoplomahija, alka i moreška; a uz njih su se izvodili i plesovi te narodna kola poput konavoskoga i župskoga kola. Sam knez pozivao je plemiće u rasponu starosti između 16 i 36 godina na sudjelovanje i izvođenje igara i plesova. S obzirom na to da dubrovačka vlada nije imala redovitu vojsku, bilo je logično da su vlasti poticale ovakva vojna natjecanja. Pobjednici natjecanja dobivali bi nagradu te su bili popraćeni svečanom svirkom bubnjeva i trubalja dok su demaskirani šetali po gradu. ${ }^{81}$

Uz ovu se proslavu veže i jedan zanimljiv zakon nazivan Sloboda svetoga Vlaha (Franchisia sancti Blasii) kojime se dopušta svima, pa čak i političkim i građanskim prijestupnicima, ${ }^{82}$ da tri dana prije i nakon proslave slobodno borave u Gradu. Ipak, ova višednevna zabava uz ples i pjesmu ponekad je znala prijeći granicu dopuštenoga. Tako Diversis ističe zakon donesen 1425. godine kojime je dubrovačka vlada pokušala zabraniti izvođenje plesa i igara u prostoru katedralne crkve tijekom same proslave.

80 Demović, Glazba i glazbenici, 15.: Godine 1434. na proslavi Svetoga Vlaha sudjelovalo je dvanaest glazbenika s hercegovačkih i bosanskih dvorova, a 1466. godine dvadeset i jedan što je gotovo dvostruko više.

81 Demović, „Glazba u renesansnom.”

82 Demović, Glazba i glazbenici, 13.: Iz zakona su isključeni ubojice i kradljivci crkvenoga inventara. 


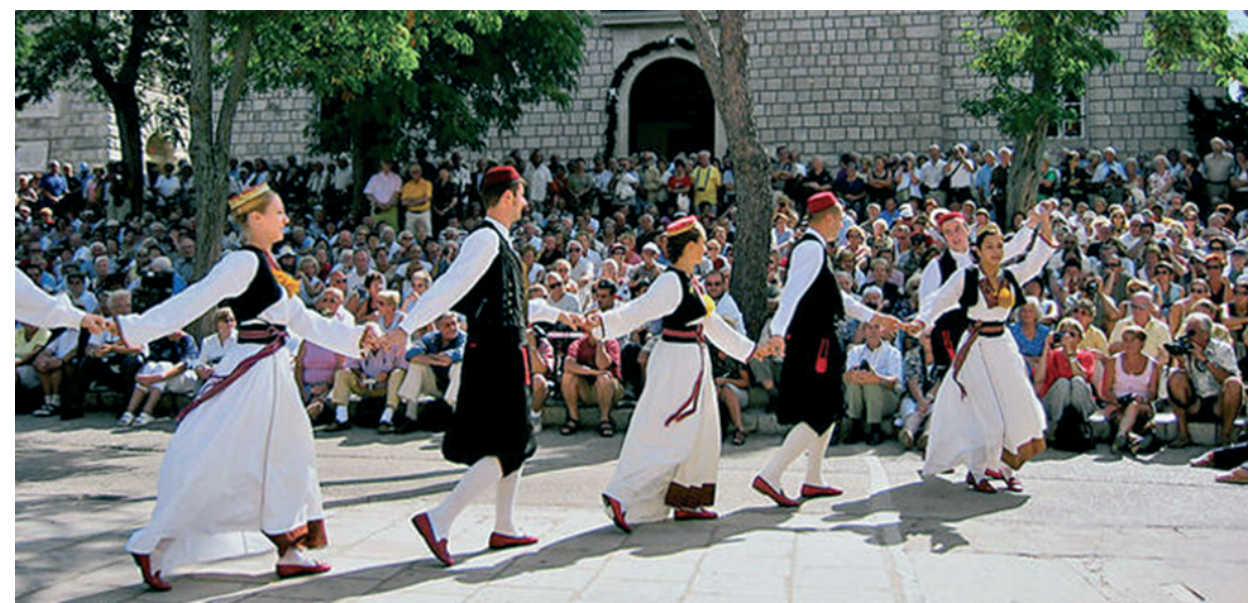

Slika 6. Plesači kola u dubrovačkim narodnim nošnjama

Proslava Svetog Vlaha svakako je bila najsjajniji blagdan u godini. Svečanost je to u kojoj je do posebnoga izražaja dolazio državni poredak oslikan savršenstvom sklada između bogato pripremljenoga crkvenog slavlja te raznolikoga društveno-zabavnog programa u kojem je glazba odigrala značajnu ulogu jer je upravo ona u svojoj raznolikosti bila ta koja je povezivala sva ključna gradska mjesta i događaje tijekom toga trodnevnog slavlja. Lonza također naglašava i kako je proslavom Svetoga Vlaha dolazilo do uspostavljanja sklada i ravnoteže svih društvenih slojeva jer su oni u svim aspektima organizacije i realizacije događaja sudjelovali zajedno kao međusobno ravnopravni. ${ }^{83}$

\section{Poklade}

Pokladno vrijeme u kojima su se odvijale karnevalske svečanosti bilo je ispunjeno veseljem, pjesmom i igrom. Zabavni program bio je dobro organiziran te je uključivao pojedine bratovštine koje su izvodile plesove i igre u okviru dvorskoga ceremonijala. U ovo vrijeme rado su se izvodile scensko-glazbene predstave među kojima su bile osobito cijenjene izvedbe mitoloških igara Bacco, Sileno, Diana i Marte; ${ }^{84}$ maškerate i složenije scenske predstave poput dramskih djela Marina Držića. Klerici su također izvodili scensko-glazbena dje-

83 Andreis, Povijest hrvatske, IV., 39-40.; Demović, Glazba i glazbenici, 13-16., Lonza, Kazalište vlasti, 238., 379.

84 Demović, Glazba i glazbenici, 17-18.: U dubrovačkoj tradiciji Turica, Bembej, Ćoroje i Vila. Glazbena im je pratnja nažalost izgubljena, ali sačuvani su slikovni prikazi njihovih kostima koje je nacrtao dubrovački tiskar Fran Martechini u 19. stoljeću. 
la u nadbiskupskoj palači u kojima su sudjelovali i glazbenici Kneževe kapele. U tim izvedbama naizmjenice se izmjenjivalo zborno i solističko pjevanje u kojem je solist predvodio zbor improvizirajući nove tekstove i melodije.

Karneval je bio vrijeme kada su ljudi mogli nesputano pokazati svoje glumačke i glazbene sposobnosti skrivenih lica iza maski. Tako su mladići i djevojke šetali ulicama okupljeni u manje sastave i uveseljavali promatrače svojom svirkom, pjesmom, plesom i dosjetkom. Za vladu ovo je bio period obilježen zabranama u kojem su neprestalno pokušali uspostaviti kontrolu nad rasporedom brojnih zabavnih događanja tj. nad prikazom „izokrenutoga“ svijeta prepunoga izrugivanja ustaljenim vrijednostima. ${ }^{85}$

\section{Pretili četvrtak (Il giovedì grasso)}

Ovo je događaj koji se najčešće odvijao krajem karnevalskoga razdoblja. Uključivao je glazbu i ples folklornoga karaktera. Naime, na taj je dan pred vladom „balala” bratovština krojača ${ }^{86}$ koju je predvodio kolovođa. Na raznim su se mjestima po gradu izvodili deset do dvanaest „šavaca.” To je bio stiliziran pastirski ples lančanoga tipa koji je sadržavao 48 plesnih figura koje su se izvodile uz pratnju puhača Kneževe kapele. Država je svakoga svirača i plesača nagrađivala jednim perperom, a od kneza su kao osobnu zahvalu dobivali kutiju slatkiša. Ples je završavao u večernjim satima na Dvoru pod svjetlima baklji. ${ }^{87}$

\section{Veliki tjedan i Uskrs}

Veliki tjedan još je jedan u nizu kršćanskih događanja u kojima se izvodila crkvena glazba. Posebno je svečana bila misa na Veliku subotu na kojoj se pjevao napjev Lumen Christi uz paljenje trostruke svijeće, simbola rasvjetljavanja mraka i odgona smrti. Nakon toga slijedio je blagoslov uskrsne svijeće popraćen pjevanjem Exultatea. ${ }^{88}$

85 Demović, Glazba i glazbenici, 16-18.; Lonza, Kazalište vlasti, 342-343.

86 Lonza, Kazalište vlasti, 339.: Ples i svirka na ovom događaju bio je jedna od povlastica, ali i obveza krojačke bratovštine.

87 Isto, 339.

88 Isto, 349-353. 


\section{Božić}

Božićni ciklus započinjao je Došašćem, a završavao večernjicom na Blagdan svetoga Ivana. U ovom razdoblju su se održavale posebno svečane misne svečanosti nakon kojih bi glazbenici Kneževe kapele pratili svirkom kneza do crkve svetoga Vlaha u kojoj se izvodila prigodna glazba u znak zahvalnosti Parcu.

U ovo vrijeme pjevale su se kolede, ${ }^{89}$ pjesme koje su izvodile manje skupine odraslih ljudi ili djece uz pratnju glazbenih instrumenata povodom određenih crkvenih blagdana. Na njihov prvi spomen nailazimo u Dubrovačkom statutu iz 1272 . godine. ${ }^{90}$ Taj je običaj kolendavanja u Dubrovniku zadržan do danas. Naime, svake godine na Badnjak ljudi se okupe te kolendavaju ispred Vijećnice kada na crkvenom zvoniku odzvoni podne. Sve započinje postavljanjem božićnoga drvca na središnje gradsko mjesto te uzdizanjem simboličnoga križa napravljenoga od voća i kićenoga grančicama lovora, bršljana, ružmarina i drugih aromatičnih biljaka na njega. Događaj je uobičajeno bio popraćen pjesmom i svirkom, a na njemu su prisustvovali građani te predstavnici građanskih i mjesnih vlasti. Nakon toga središnjeg događaja skupine mladih ljudi išle bi od jedne do druge kuće ispred kojih bi pjevali prigodne vesele popijevke religioznoga i šaljivoga karaktera. Tekstovi pjesama uglavnom su bili improvizirani, ali u svojoj glavnini sadržavali su čestitku ukućanima za nadolazeće blagdane. Za svoj trud tražili su simboličan dar u obliku novca ili slastica. Ako ga ne bi primili, upućivali bi domaćinima podrugljive stihove. Kolede su, s obzirom na tekst koji je pratio dionice ophoda, imale tri dijela. U prvom dijelu pjesme kolendari su pozdravljali ukućane pjevajući pod njihovim prozorom ili pred njihovim kućnim vratima. Zatim bi se u pjesmi poimence spomenuli svi članovi obitelji počevši od njezinoga najstarijeg i najuglednijeg člana. Završni dio kolede sastojao se od rima u kojima su koledari tražili darove za

89 Marko Dragić, Poetika i povijest hrvatske usmene književnosti, Preuzeto s: https://www. ffst.unist.hr/images/50013808/poetika\%20i\%20povijest.pdf (15.9.2017.): Koleda (kolenda) riječ je koja potječe od latinskoga glagola caleo (zazivati) ili latinske riječi calendae (prvi dan u mjesecu).

Preuzeto s: https://www.ffst.unist.hr/images/50013808/poetika\%20i\%20povijest.pdf (15. 9. 2017.))

90 Demović, Glazba i glazbenici, 17-18.:Određuje se da knezu trebaju „kolendati mornari, a knez ih treba obdariti božićnim darovima." Također se navodi da su nadbiskupu klerici bili obvezni pjevati kolende. 
svoj trud. Tako je u dubrovačkom kraju bilo uobičajeno darivanje koledara smokvama ili orasima. ${ }^{91}$

\section{Pirne svečanosti}

Pirne svečanosti u starom su se Dubrovniku odvijale u veoma svečanom tonu te su uvijek bile popraćene glazbom. Prvi opis takvih svečanosti donosi Filip de Diversis sredinom 15. stoljeća. Glazbena pratnja okupljala se ispred kuće mladenaca te ih je svirkom pratila na putu od kuće prema crkvi. Glazbenici su svirali i tijekom samoga čina vjenčanja te naposljetku na povratku mladenaca od crkve do mjesta gdje se odvijalo pirno slavlje. Mladence su od kuće do crkve i natrag pratile grupe momaka i djevojaka koji su ponekad ispred mladenaca po ulicama izvodili plesove poput "ballo de fantasche” i „colla" pod maskama. Njihov je ples također bio popraćen glazbom.

Slavlje bi u mladoženjinoj kući znalo potrajati i po nekoliko dana pa su domaćini morali organizirati prigodan zabavni program za svoje goste. Tako su se u nekim bogatijim kućama znala izvoditi i scenska djela uz glazbenu pratnju poput nekih Držićevih komedija. ${ }^{92}$ Gradski glazbenici bili su dužni svirati na ovakvim slavljima pod prijetnjom kazne od pet perpera od gradskih vlasti. ${ }^{93} \mathrm{~S}$ druge strane, dubrovački Senat zakonski je nekoliko puta pokušao regulirati i preraskošna pirovanja poznatom „Odredbom protiv suzbijanja raskoši." ${ }^{94}$

\section{Natjecanja svirača}

U Dubrovniku su se znala održavati i javna natjecanja svirača u skladanju o čemu nam svjedoči jedan podatak iz zapisnika Vijeća umoljenih. Naime, 20. lipnja 1504. godine održano je natjecanje između dvojice svirača Kneževe kapele, trombonista Laurentiusa Manesa ${ }^{95}$ i Markete Saracena. ${ }^{96}$ Veću uspješnost u umijeću skladanja popijevki

91 Stipe Botica, Hrvatska usmenoknjiževna čitanka, Zagreb, 1995., 46.; M. Demović, Glazba i glazbenici, 17-18.; M. Demović, „Glazba u renesansnom.” Preuzeto s: https://hrcak.srce. hr/file/152541 (5.7.2017); M. Dragić, Poetika i povijest. N. Lonza, Kazalište vlasti, 336.

92 Demović, „Glazba u renesansnom”: Tako su izvedene „Tirena, „Venera i Adon” te „Novela od Stanca.”

93 Isto: U vrijeme kada je zakon donesen (1434.) kazna od pet perpera bila je poprilično visoka novčana kazna.

94 Isto.

95 Demović, Glazba i glazbenici, 82-84.: U Dubrovniku nazivan Lovro.

96 Isto: S obzirom na Marketin nadimak Saraceno i Negro te na vrijeme njegova djelovanja u Dubrovniku (o. 1504. - 1539.), Demović ga povezuje s osobom Machetta Care, talijanskoga skladatelja koji je djelovao na dvoru Gonzaga u Mantovi sredinom 15. stoljeća stekavši ime najplodnijega skladatelja renesansnog vokalno-instrumentalnog oblika frottole. 
pokazao je Laurentius Manes te je on prema odluci žirija, koji su sačinjavali orguljaš Eduard i redovnik Benedikt iz dominikanskoga samostana, proglašen pobjednikom.

Ovaj zapis služi nam kao svojevrsna potvrda da je u Dubrovniku početkom 16. stoljeća postojao kadar visoko kvalificiranih glazbenikaskladatelja zbog kojih je održavanje ovakvih natjecanja i bilo moguće. Zapis nam također daje uvid u kompetitivnu atmosferu koja je vladala među glazbenicima Kneževe kapele. ${ }^{97}$

\section{Zaključak}

Zbog nedostatka arhivskih dokumenata i notne građe koji su nepovratno izgubljeni tijekom velike trešnje 1667., veoma je teško rekonstruirati cjelovitu sliku dubrovačke renesansne instrumentalne i vokalne glazbe. Ipak, u mnogim književnim djelima sačuvane su glazbene reference koje nam svjedoče o dubrovačkoj glazbi 15. i 16. stoljeća. Demović uočava da je u dubrovačkoj renesansnoj glazbi zadržana srednjovjekovna podjela na crkvenu i svjetovnu sferu te da su se stoga ove sfere razvijale u različitim smjerovima. Crkvena se glazba razvijala unutar katedralnih škola pretežito njegujući višeglasno zborsko a cappella pjevanje uz povremenu pojavu orguljaške pratnje. U instrumentalnoj glazbi ovoga vremena svakako je bila dominantna uloga orgulja, instrumenta koji je zahtijevao svirača razvijenih glazbenih sposobnosti i dobroga razumijevanja glazbene teorije. Nezavisnost Dubrovačke Republike i njezina otvorenost prema strancima privlačila je mnoge strane umjetnike u Grad koji su nerijetko ondje ostajali i živjeti, na kraći ili duži period. Ti su umjetnici, među kojima su se posebno istaknuli glazbenici iz obitelji Courtois, utjecali na razvoj dubrovačke vokalne i instrumentalne glazbe. Dubrovačka je Republika posebnu važnost pridavala održavanju svoga ugleda, a u tome su joj uvelike pomagali glazbenici okupljeni u Kneževoj kapeli. Nella Lonza u svom djelu Kazalište vlasti ističe važnost državnoga ceremonijala i uloge koju je glazba imala u njoj.

Glazba je također imala veliku ulogu u čovjekovu svakodnevnom životu. Ona se izvodila u različitim prilikama kao npr. tijekom crkvenih i državnih proslava, vjenčanja i plemićkih zabava, ali i tijekom izvršavanja smrtnih presuda i na sprovodima. Duboka povezanost glazbe s

97 Demović, Glazba i glazbenici, 82-84.; Demović, „Glazba u renesansnom.”; Tuskar, „Dubrovački ranobarokni." 
plesom i književnošću, visokoga ili niskoga stila, uvijek je davala nove impulse i inspiracije za nastajanje novih djela od kojih je danas nažalost veoma malo sačuvano.

\section{SUMMARY}

Today only literature and a few musical pieces bear witness what music life in the 15th and 16th century Dubrovnik looked like. The development of church music had its own separate way regarding secular music. The church music was developed in cathedral schools and performed mostly a cappella. When talking about instrumental church music, we should underline the role of the organ as the most dominant instrument which required high playing skills and good knowledge of musical theory. On the other hand, the company of musicians gathered in the Rector's Palace, sponsored by the government, performed mostly secular music but also participated in church festivities and fairs. Even though the music played an important role in the official government matters, it also held a key role in everyday life.

Key words: The Dubrovnik Republic, ecclesiastical and secular music, musicians, the Renaissance musical instruments, performing music, 15th and 16th century 


\section{Bibliografija}

\section{Knjige i članci}

Andreis, Josip. Povijest glazbe, I. Zagreb: Liber, 1975.

Andreis, Josip. Povijest hrvatske glazbe, IV. Zagreb: Liber, 1974.

Botica, Stipe. Hrvatska usmenoknjiževna čitanka. Zagreb: Školska knjiga, 1995.

Courtoys, Lambert st. U Hrvatski biografski leksikon. Preuzto s: http://hbl.lzmk.hr/ clanak.aspx?id=3698 (7. 8. 2017.).

Demović, Miho. „Dubrovački ranobarokni skladatelj Vicenco Komnen (1590. 1667.)", U Rad, 377 (1978): https://dizbi.hazu.hr/object/10840 (2. 8. 2018.).

Demović, Miho. Glazba i glazbenici u Dubrovačkoj Republici: od početka XI. do polovine XVII. stoljeća. Zagreb: JAZU, 1981.

Demović, Miho. „Glazba u renesansnom Dubrovniku.” Dani Hvarskoga kazališta: Građa i rasprave o hrvatskoj književnosti i kazalištu 14/1 (1988): https://hrcak.srce. hr/file/152541 (5. 7. 2017.).

Dragić, Marko. Poetika i povijest hrvatske usmene književnosti. Split: Filozofski fakultet, Sveučilišta u Splitu, 2007. Preuzeto s: https://www.ffst.unist.hr/images/50013808/poetika\%20i\%20povijest.pdf (15. 9. 2017.).

Foretić, Vinko. Povijest Dubrovnika do 1808, II. Zagreb: Nakladni zavod MH, 1980.

Glazba. U Leksikon Marina Držića. Preuzeto s: http://leksikon.muzej-marindrzic.eu/ glazba/ (20. 7. 2017.).

Harris, Robin. Povijest Dubrovnika. Zagreb: Golden marketing - Tehnička knjiga, 2006.

Kos, Koraljka. „Muzički instrumenti u srednjovjekovnoj likovnoj umjetnosti Hrvatske", U Rad, Zagreb, 351/2 (1969)

Lonza, Nella. Kazalište vlasti. Ceremonijal i državni blagdani Dubrovačke Republike u 17. i 18. stoljeću. Dubrovnik: HAZU, 2009.

Medini, Milorad. Povijest hrvatske književnosti u Dalmaciji i Dubrovniku, I. Zagreb: Matica hrvatska, 1902.

Primorac, Jakša. Poj ljuveni: Pučko pjevanje u renesansnoj Dalmaciji. Split: Književni krug, 2013.

Razzi, Serafin. Povijest Dubrovnika. Dubrovnik: MH, 2011.

Sorić, Ante, ur. Zlatno doba Dubrovnika: XV. I XVI. stoljeće: urbanizam, arhitektura, skulptura, slikarstvo, iluminirani rukopisi, zlatarstvo. Zagreb: MTM, 1987.

Stipčević, Enio. „Dominikanci i glazba u Hrvatskoj (16. - 20. stoljeće).” U Croatica Christiana periodica, 35/67 (2011). Preuzeto s: https://hrcak.srce.hr/74297 (13. 8. 2018.).

Tuskar, Stanislav. „Dubrovački ranobarokni skladatelj Vinko Komnen i mreža njegovih odnosa s prethodnicima i suvremenicima." U Arti musices: hrvatski muzikološki zbornik, 46/1 (2015): http://hrcak.srce.hr/file/211888 (3. 9. 2017.).

Županović, Lovro. Stoljeća hrvatske glazbe. Zagreb: Školska knjiga, 1980. 


\section{Ilustracije:}

Slika 1.

https://www.dubrovnikcard.com/wp-content/uploads/2016/01/Istocni-dio-atrijaKnezeva-dvora-sa-spomenikom-Mihu-Pracatu.jpg (20. 8. 2018.)

\section{Slika 2.}

http://leksikon.muzej-marindrzic.eu/wp-content/uploads /2014/06/ dobricevic-andjel.jpg (5. 9. 2017.)

Slika 3. Grafički prikaz napravljen prema Demović, Miho. Glazba i glazbenici u Dubrovačkoj Republici: od početka XI. do polovine XVII. stoljeća. Zagreb: JAZU, 1981.: 285-230.

Slika 4. Demović, Miho. Glazba i glazbenici u Dubrovačkoj Republici: od početka XI. do polovine XVII. stoljeća. Zagreb: JAZU, 1981.: 61-62.

Slika 5. http://www.brotnjo.info/wp-content/uploads/2018/01/sveti_vlaho.gif (20. 8. 2018.)

Slika 6. https://www.korkyra-dubrovnik.com/images/services_e_l_cilipi.jpg (20. 8. 2018.) 